\title{
Analyzing Water Quality in Darbandikhan Reservoir, Kurdistan Region, Iraq
}

\author{
Saima Jadoon', Sarfraz Munir², Ahmad Majid Abdulhamid ${ }^{3}$ \\ ${ }^{1}$ Department of Natural Resources Engineering and Management University of Kurdistan Hewlêr, 30 Meter Avenue, Erbil, Kurdistan
} Region, Iraq

\author{
${ }^{2}$ Department of Natural Resources Engineering and Management University of Kurdistan Hewlêr, \\ 30 Meter Avenue, Erbil, Kurdistan Region, Iraq \\ ${ }^{3}$ Department of Natural Resources Engineering and Management University of Kurdistan Hewlêr, \\ 30 Meter Avenue, Erbil, Kurdistan Region, Iraq
}

\begin{abstract}
The present study aims to understand the water quality of Darbandikhan Reservoir by calculating the Water Quality Index (WQI), and finding correlations amongst various water quality parameters as well as with climate variations. In this study, the ten physical and chemical water quality parameters were measured in Darbandikhan Reservoir such as pH, conductivity, total dissolved solids (TDS), dissolved Oxygen, turbidity, nitrates, total hardness, calcium, iron and chlorides. Water samples were collected from eleven different locations in the reservoir in order to observe the spatial variation of water quality in the reservoir. Based on these measurements, the Water Quality Index (WQI) is calculated. In addition to this, secondary data were also collected for about two years at upstream and downstream of the dam which were used to develop the correlations. The observed results are compared with water quality standards, and the water quality index is applied for Darbandikhan Reservoir. The WQI can be used as an indicator to evaluate water quality of the reservoir, whereas correlations can be used to predict the water quality in the future by measuring the independent variables.
\end{abstract}

Keywords: Analyzing water, WQI, Reservoir, Darbandikhan

\section{Introduction}

Water is the most significant requirement for all living creatures on this planet so appropriate care should be given to this important resource. Water resources are of critical importance to both natural ecosystems and human development, and it is essential for human life, industry and agriculture. Healthy aquatic ecosystem is depended on the biological, chemical and physical characteristics [1].

Kurdistan is a region located in the northern part of Iraq, and it has many water resources like ground water and surface water including rivers, lakes, dams and reservoirs, and those resources have their own significance and their own benefits. Generally, reservoirs or dams that can be called artificial lakes are built because of providing some benefits like providing water supply, controlling floods, making the nature more beautiful, hydro-electric power or fish and wildlife habitat. One of the basic reasons for building a dam is to accumulate water and save it for different seasons and provide water when it is needed. The quality of water in any reservoir or dam is important, because the water will impact the environment and the water will be used for various purposes. Assessing the water quality resources is a necessary method in the improvement of water resources. Water quality may be defined in terms of particular features of water [2].

Darbandikhan Reservoir is like other reservoirs where deterioration will occur in the quality of water because of differences of different parameters and heavy metals in the water, so that means the quality of water is dependent on different parameters and the amount of heavy metals that exist in the water. Also there are different other environmental impacts which have influences on the water quality like rainfall and water temperature. When surface water like lakes and reservoirs are analyzed based on those different parameters, the environmental effects like rainfall and water temperature should be considered during the research. Darbandikhan is listed along with Dukan as an important place for birds in Kurdistan, and the lake is surrounded by hills which are covered by grass, small shrubs and mountains (including Bashari, Zmnako and Zawaly) that are covered in oak forests. The use of the physiochemical properties of water to evaluate the quality of the water gives a good impression of the efficiency and sustainability of such water bodies [3].

Darbandikhan reservoir is a deep, large and fresh water lake, and it is located $65 \mathrm{~km}$ southeast of Sulaymaniah City. It is fed by two rivers, Sirwan in the southeast and Tanjaro in the northeast. It is known that there are some obvious problems that exist in the Darbandikhan reservoir and the Tanjaro basin in particular due to sewage inputs from the city of Sulaymaniah and other towns and villages. Also heavy metals have been found in the water and sediments in different areas of the basin, and there may be other issues that may be impacting the quality of the water in Darbandikhan Reservoir [4].

In this project, analyzing water quality focused on the Darbandikhan Reservoir/Dam whose water is used for different purposes like water supply, generating power, flood control, irrigation and fisheries. The water quality can be determined by specific analysis called Water Quality Index (WQI) using specific parameters. It is highly recommended

\section{Volume 4 Issue 12, December 2015}




\section{International Journal of Science and Research (IJSR) \\ ISSN (Online): 2319-7064 \\ Index Copernicus Value (2013): 6.14 | Impact Factor (2014): 5.611}

that the water must be checked and tested continuously to make sure its quality follows the required and standard level of water quality, and the water quality index will be prepared for Darbandikhan Reservoir by using different chemical and physical parameters like $\mathrm{pH}$, turbidity, DO, TDS, conductivity, calcium $(\mathrm{Ca})$, chloride, iron $(\mathrm{Fe})$, nitrate (NO3) and total hardness.

\subsection{Objectives}

In the light of the problem statement, the objectives of the study are to:

1. Assess the water quality status of Darbandikhan Reservoir for various purposes by calculating the Water Quality Index (WQI) of Darbandikhan Reservoir, and identifying class of the water.

2. Find correlations among water quality parameters and between climate and water quality.

\section{Methodology}

Darbandikhan Dam/reservoir is located on the Diyala Sirwan river approximately $65 \mathrm{~km}$ south-east of Sulaymaniah and $230 \mathrm{~km}$ north-east of Baghdad, and its boundaries extended from latitude $35^{\circ} 6^{\prime}-35^{\prime} \prime \mathrm{N}$ and longitudinal $45^{\circ} 41^{\prime}-20^{\prime}$ ' E. The map of the location is shown in figure 1. [5].

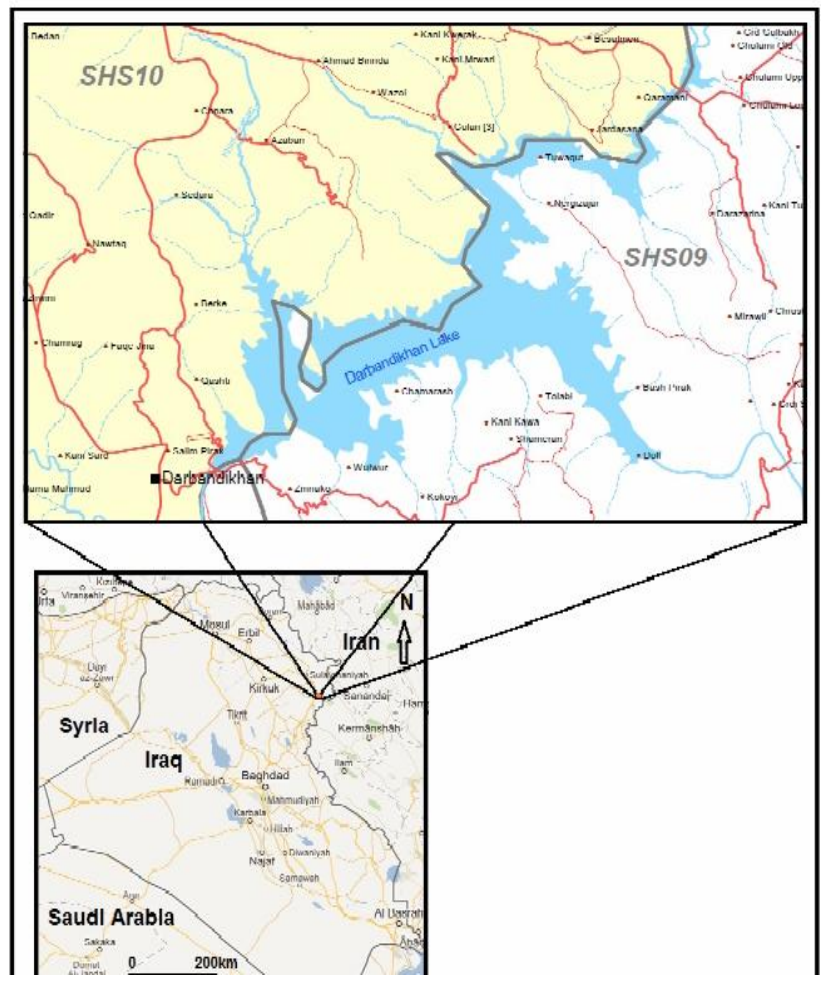

Figure 1: Location of Darbandikhan reservoir on the map

Harza engineering company of the United States of the America designed Darbandikhan Dam for the Iraqi Government, and the construction of the dam started in 1956 and finished in the summer of 1961. The type of the dam is an embankment dam with a central clay core and rock fill shoulder, and pertinent data of Darbandikhan Dam will be shown in the annex 1. The catchment area of the dam is $17,850 \mathrm{~km}^{2}$, and the maximum height of the main structure is
$128 \mathrm{~m}$. When the elevation of the water is $485 \mathrm{~m}$ above sea level (ASL), the reservoir area is $113 \mathrm{~km} 2$ and its volume is $3000 \mathrm{Mm} 3$ of which $2500 \mathrm{Mm} 3$ is live storage and $500 \mathrm{Mm} 3$ is dead storage. The dam is controlled by spill way on the side of the bank to prevent any damages that will be cause by flood, and three tainter gates were installed on the spillway which is shown in figure 2. [5].

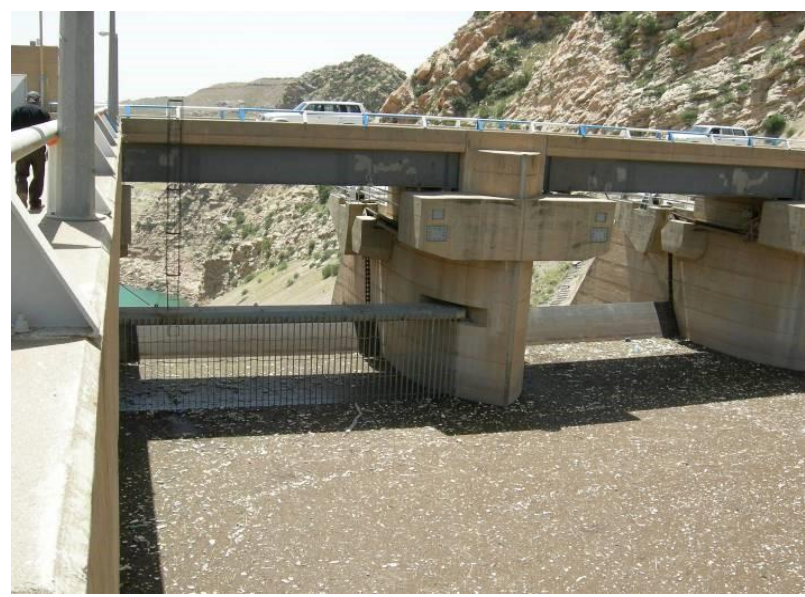

Figure 2: Spillway gate No. 3 of Darbandikhan Dam.

\subsection{Data collection and data requirements}

This study is calculates water quality index in order to investigate the quality of water in the Darbandikhan Reservoir, and may assist the scientific community and the government as a record for future improvements.

For analyzing and calculating water quality index, the measurement of the different water quality parameters and those factors which will impact the reservoir are needed for this investigation.

\subsubsection{Data collection}

The secondary data collected from the directorate of Darbandikhan dam for their lab analyses [6], include monthly average rainfall and water temperature [5]. Lab analyses data for two years collected from December of 2012 to December of 2014 , but for 5 months the tests had not been done by directorate of the dam to assess the water quality from August of 2013 to January 2014.

Computing WQI in the whole reservoir will not be accurate because some of the important parameters are not included or could not be read by the machine of their lab because of the capability of the machines, and they took samples just in the upstream and downstream of the dam. Therefore, primary data is needed for having precise WQI value in the entire reservoir and in order to get primary data, water sampling from the reservoir is required.

\subsubsection{Data requirements}

From the review, it has been indicated that numbers of parameters needed for calculating WQI, and some parameters will influence on the value of WQI. The parameters have been chosen for calculating WQI:

Conductivity, $\mathrm{pH}$, TDS, DO, Turbidity, Total hardness, Nitrates, Chloride, Calcium, Iron. 


\section{International Journal of Science and Research (IJSR) \\ ISSN (Online): 2319-7064}

Index Copernicus Value (2013): 6.14 | Impact Factor (2014): 5.611

The other parameters that will impact the quality of water in the reservoir:

Water temperature, Rainfall.

\subsubsection{Sampling method}

a. Quality of sampling

There are different types of sampling, but the method which is used for this project was random sampling that gives equal chance for any part of the reservoir. The area of the reservoir was divided in to different parts and samples were taken from each.

- How were samples taken?

The samples were taken at the depth of $3 \mathrm{~m}$ in order to avoid scums which exists in the water and to give accurate result by having a pipeline which its' length was $3 \mathrm{~m}$, and there were a check valve on a side then we put it in the water. After the pipe filled with water, then the water was released in to the bottles.

After placing the water in to the bottles, the head of the bottles was closed directly to avoid allowing any environmental effects. Then, the related descriptions to sampling were written on a paper and attached to the bottle by tape.

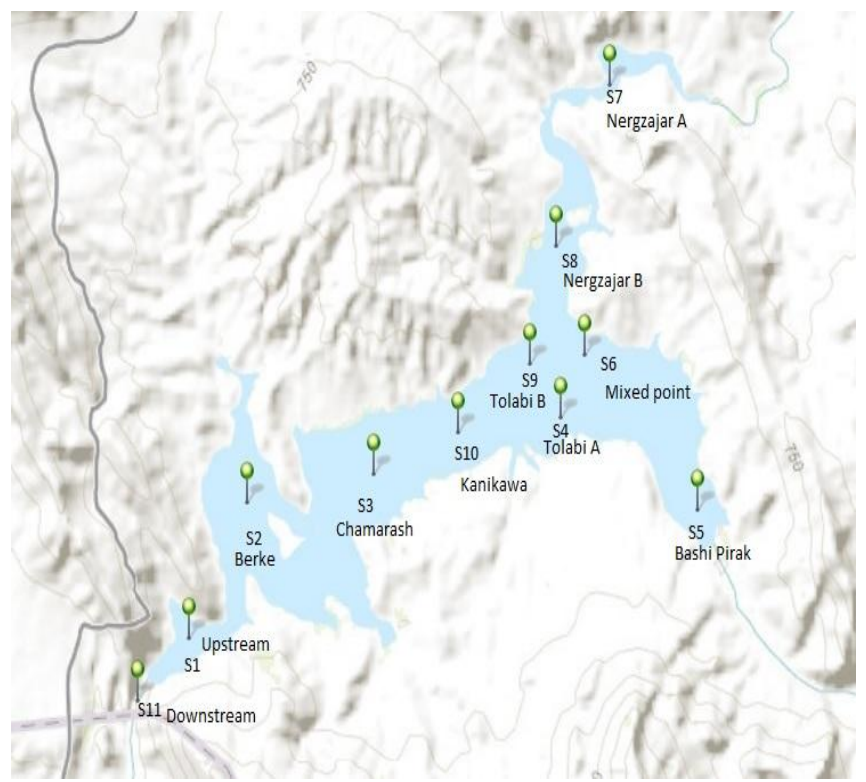

Figure 3: Location and name of the water samples collection points in the Darbandikhan Reservoir.

The descriptions include:

Name of sampler, Date and time of sampling, Name or number of the sample or both, Coordinates of the location

The location and the number of samples are shown in the Figure 3.

\section{b. Sampling preparation}

The way of sample preparation is the significant part of sampling, and some points should be considered such as the weather on the day should be fine and all the materials should be prepared which were needed for sampling.
The materials needed for taking samples:

1. Those equipment that needed for field analyses

2. GPS for determining the location and map

3. Bottles and bag for those bottles

4. Field data form, Marker, notebook, pen, paper and tape

5. Pipeline $(3 \mathrm{~m})$ for taking samples

\subsection{Data analysis}

For investigating in this research and evaluating the quality of the water, three different kinds of analyses will be needed in order to measure the water quality parameters and calculate WQI.

\subsubsection{Field analyses}

One of the important analyses needed for measuring six parameters should be done in the field without taking the samples back to laboratory and allowing time and environmental effects to impact them. Those six parameters will be shown in table 1 with its units and the machines that are used for measuring.

\section{a. Procedure of field analyses:}

By using afore mentioned instruments in table 1 those parameters of water measured in the field, but after measuring each sample, the instruments are washed by distilled water in order to avoid effects of the previous sample on the next one. During measuring, time was needed for determining the value of water quality parameters, because the readings should be stable.

Table 1: Water quality parameters that measured in the field

\begin{tabular}{|c|c|c|c|}
\hline No. & Parameter & units & Test methods \\
\hline 1 & PH & - & Plainest micro 600 PH meter \\
\hline 2 & Turbidity & NTU & $\begin{array}{c}\text { Plainest micro 600Turbidity } \\
\text { meter }\end{array}$ \\
\hline 3 & Conductivity & $\mu \mathrm{s} / \mathrm{cm}$ & $\begin{array}{c}\text { Micro 600 conductivity TDS } \\
\text { meter }\end{array}$ \\
\hline 4 & TDS & $\mathrm{mg} / \mathrm{L}$ & $\begin{array}{c}\text { Plainest micro 600 } \\
\text { conductivity TDS meter }\end{array}$ \\
\hline 5 & DO & $\mathrm{mg} / \mathrm{L}$ & Plainest DO6+ D.O./temp \\
\hline 6 & Water temperature & ${ }^{\circ} \mathrm{C}$ & $\begin{array}{c}\text { Mercury-in-glass } \\
\text { thermometer }\end{array}$ \\
\hline
\end{tabular}

\subsubsection{Laboratory analyses}

The other water quality parameters needs laboratory and chemical methods for measuring and observing the outcomes. The name of parameters, units and the methods for measuring is shown in table 2 .

Table 2: Water quality parameters need laboratory

\begin{tabular}{|c|c|c|c|}
\hline No. & Parameter & unit & Test methods \\
\hline 1 & Nitrates & $\mathrm{mg} / \mathrm{L}$ & $\begin{array}{c}\text { Jenway 6705 U.V visible } \\
\text { spectrophotometer }\end{array}$ \\
\hline 2 & Total Hardness & $\mathrm{mg} / \mathrm{L}$ & $\begin{array}{c}\text { Digital burette (Titration EDTA } \\
\text { method) }\end{array}$ \\
\hline 3 & Calcium & $\mathrm{mg} / \mathrm{L}$ & Flame photometer \\
\hline 4 & Chloride & $\mathrm{mg} / \mathrm{L}$ & $\begin{array}{c}\text { Digital burette (Argentometric } \\
\text { titration) }\end{array}$ \\
\hline 5 & Iron & $\mathrm{mg} / \mathrm{L}$ & $\begin{array}{c}\text { Buck scientific /model A8000 } \\
\text { Flame atomic absorption } \\
\text { spectrophotometer }\end{array}$ \\
\hline
\end{tabular}




\section{International Journal of Science and Research (IJSR) \\ ISSN (Online): 2319-7064 \\ Index Copernicus Value (2013): 6.14 | Impact Factor (2014): 5.611}

\subsubsection{Procedure of lab analyses}

The $\mathrm{pH}$, TDS, conductivity and turbidity of water samples were measured by using $\mathrm{pH}$ meter, TDS meter, conductivity meter and turbidity meter (600 modle Plaintest micro, UK). The total hardness of water samples were measured by EDTA titration method [6]. The concentration of chloride in water samples was measured by Argentometric titration [7] .Nitrate was determined in water samples with help of UV/Visible Spectrophotometer (modle $6705 \mathrm{UV} / \mathrm{Vis}$ Jenway, UK) [8]. Digital burette is used to determine the concentration of sulphate in water [9].Total alkalinity of samples was checked by using digital burette (Bibby scientific) [10]. Concentration metal cat ions (Sodium, Potassium, and Calcium) were determined by using a flame photometer (model PFP7 Jenway, UK) [11], [12]. Total coliform (Bacteria) was tested in water samples [13].

\section{Calculating WQI}

The method and formulas that was used to compute WQI [14]: First, the basic formula of water quality index equals the summation of the sub-indices.

$$
W Q I=\sum_{i=1}^{n} S I
$$

$\mathrm{SI}_{\mathrm{i}}$ : sub-indices for WQI

So the $\mathrm{SI}_{i}$ calculated from

$$
S I_{i}=R W * Q_{i}
$$

RW: is relative weight which is found from assigned weights for each parameter, and it can be calculated from

$$
R W=\frac{A W_{i}}{\sum_{i=1}^{n} A W_{i}}
$$

$\mathrm{Q}_{\mathrm{i}}$ : is quality rating for the parameters which can be calculated from

$$
Q_{i}=\frac{c_{i}-V_{i}}{s_{i}-V_{i}} * 100
$$

$\mathrm{C}_{\mathrm{i}}=$ concentration of the parameter in the water

$\mathrm{S}_{\mathrm{i}}=$ standard value for each parameter. The values that were used are suggested by WHO, Iraqi Standard, Indian Standards and New Delhi. [14], [17], [18].

$\mathrm{V}_{\mathrm{i}}$ : is the ideal value which is zero for all parameters except $\mathrm{PH}$ considered as (7) and DO considered as (14.6).

From the calculated WQI, the water can be classified.

\section{Statistical analyses}

After having the results from directorate of Darbandikhan dam, and results from the sampling which are field analyses, laboratory analyses and calculated WQI, statistical analysis was completed by using Microsoft Office Excel program for finding correlations between water quality parameters and other environment parameters which impact the quality of water like rainfall and water temperature.

\section{Result and Discussion}

In this chapter, the results of water quality observations and analysis, including the correlation between climate variability on the water quality variations are presented.

\subsection{Spatial variation in Water Quality of the Reservoir}

The results of the observed parameters of water quality and the water quality index are shown in the subsequent sections which are calculated from the taken samples. The detailed data about water quality parameters, WQI, time and locations are given in table 3 .

Table 3: Shows detailed data about water quality parameters

\begin{tabular}{|l|c|c|c|c|c|c|c|c|}
\hline Samples & TDS & Nitrate & Total Hardness & Chloride & DO & Calcium & Iron & $\sum$ WQI \\
\hline 1 Qashli & 324 & 5.20 & 80 & 81.65 & 9.86 & 29.8 & $\mathrm{Fe}<1 \mathrm{mg} / 1$ & 56.8 \\
\hline 2 Berke & 796 & 4.20 & 90 & 77.4 & 9.83 & 28.5 & $\mathrm{Fe}<1 \mathrm{mg} / 1$ & 82.4 \\
\hline 3 Chamarash & 783 & 4.40 & 80 & 73.13 & 9.82 & 29.6 & $\mathrm{Fe}<1 \mathrm{mg} / 1$ & 80.8 \\
\hline 4 Tolabi A & 842 & 2.70 & 160 & 60.35 & 9.8 & 32 & $\mathrm{Fe}<1 \mathrm{mg} / 1$ & 96.1 \\
\hline 5 Bashi Pirak & 822 & 4.43 & 64 & 73.8 & 9.83 & 35 & $\mathrm{Fe}<1 \mathrm{mg} / 1$ & 103.5 \\
\hline 6 mixed point & 775 & 4.45 & 100 & 85.91 & 9.86 & 30 & $\mathrm{Fe}<1 \mathrm{mg} / 1$ & 80.3 \\
\hline 7 Nergzajar A & 816 & 6.60 & 76 & 73.1 & 9.8 & 33.3 & $\mathrm{Fe}<1 \mathrm{mg} / 1$ & 84.9 \\
\hline 8 Nergzajar B & 793 & 5.40 & 80 & 71 & 9.77 & 30.5 & $\mathrm{Fe}<1 \mathrm{mg} / 1$ & 81.0 \\
\hline 9 Tolabi B & 781 & 5.30 & 72 & 98 & 9.76 & 31.3 & $\mathrm{Fe}<1 \mathrm{mg} / 1$ & 81.4 \\
\hline 10 Kani Kawa & 779 & 4.40 & 100 & 57.5 & 9.79 & 29.7 & $\mathrm{Fe}<1 \mathrm{mg} / 1$ & 81.2 \\
\hline 11 D/S & 788 & 5.20 & 69.8 & 100.1 & 9.7 & 32.2 & $\mathrm{Fe}<1 \mathrm{mg} / 1$ & 82.3 \\
\hline
\end{tabular}

\subsubsection{Dissolved Oxygen and $\mathrm{pH}$}

DO represents the amount of oxygen dissolved in the water, and $\mathrm{pH}$ shows water has acidic or basic (alkalinity) properties. The results are shown in Table 3.1 for dissolved oxygen and in Table 3.2 for $\mathrm{pH}$.

Table 4: Results of DO concentration

\begin{tabular}{|c|c|c|}
\hline Sample No. & Sampling Location & $D O(\mathrm{mg} / \mathrm{l})$ \\
\hline 1 & Qashli & 9.86 \\
\hline 2 & Berke & 9.83 \\
\hline 3 & Chamarash & 9.82 \\
\hline 4 & Tolabi A & 9.80 \\
\hline 5 & Bashi Pirak & 9.83 \\
\hline 6 & mixed point & 9.86 \\
\hline 7 & Nergzajar A & 9.80 \\
\hline 8 & Nergzajar B & 9.77 \\
\hline 9 & Tolabi B & 9.76 \\
\hline 10 & Kani Kawa & 9.79 \\
\hline 11 & D/S & 9.70 \\
\hline
\end{tabular}

Volume 4 Issue 12, December 2015 


\section{International Journal of Science and Research (IJSR) \\ ISSN (Online): 2319-7064 \\ Index Copernicus Value (2013): 6.14 | Impact Factor (2014): 5.611}

From the results, it is evident DO is changing in the reservoir. The amount of dissolved oxygen is almost close to each other and it is between 9.70 and $9.86 \mathrm{mg} / \mathrm{l}$ and the average DO in the reservoir is $9.80 \mathrm{mg} / \mathrm{l}$. All the samples were collected from a depth of 3 meters and the amount of oxygen which can percolate out from the water will be approximately the same. So, the concentration of DO in the water somehow close to each other, and it is at a safe limit.

Table 5: Results of $\mathrm{pH}$ in the reservoir

\begin{tabular}{|c|c|c|}
\hline Sample No. & Sampling Location & $p H$ \\
\hline 1 & Qashli & 7.70 \\
\hline 2 & Berke & 8.22 \\
\hline 3 & Chamarash & 8.07 \\
\hline 4 & Tolabi A & 7.83 \\
\hline 5 & Bashi Pirak & 7.97 \\
\hline 6 & mixed point & 8.31 \\
\hline 7 & Nergzajar A & 8.15 \\
\hline 8 & Nergzajar B & 8.18 \\
\hline 9 & Tolabi B & 8.34 \\
\hline 10 & 10 Kani Kawa & 8.29 \\
\hline 11 & 11 D/S & 8.18 \\
\hline
\end{tabular}

Average $\mathrm{pH}$ of the reservoir is 8.11 , and the range of $\mathrm{pH}$ was between 7.7 to 8.34 . It can be said that the water in the Darbandikhan Reservoir is somehow alkaline but mainly neutral, and it is at the safe limit as per Iraqi Standards and where permissible, the value is in between 6.5 and 8.5. The minimum observed $\mathrm{pH}$ value in the reservoir is 7.7 from sample 1 (Qashli). The location of Qashli is shown in Figure 2.3. The maximum $\mathrm{pH}$ is 8.34 , from sample 9 (Tolabi B). Over all, there is little variation in $\mathrm{pH}$ in the reservoir.

\subsubsection{Conductivity and TDS}

Conductivity and TDS are two other parameters which are tested to determine the water quality of the reservoir, and the results of the samples are presented in Table 5 .

Table 6: TDS and Conductivity of the samples

\begin{tabular}{|c|c|c|c|}
\hline & Sampling Location & Conductivity $(\mu \mathrm{S} / \mathrm{cm})$ & TDS $(\mathrm{ppm})$ \\
\hline 1 & Qashli & 461 & 324 \\
\hline 2 & Berke & 1100 & 796 \\
\hline 3 & Chamarash & 1107 & 783 \\
\hline 4 & Tolabi A & 1196 & 842 \\
\hline 5 & Bashi Pirak & 1161 & 822 \\
\hline 6 & Mixed point & 1012 & 775 \\
\hline 7 & Nergzajar A & 1191 & 816 \\
\hline 8 & Nergzajar B & 1105 & 793 \\
\hline 9 & Tolabi B & 1109 & 781 \\
\hline 10 & Kani Kawa & 1083 & 779 \\
\hline 11 & D/S & 1111 & 788 \\
\hline
\end{tabular}

Conductivity is a measure of how well water can pass an electrical current. It is an indirect measure of the presence of inorganic dissolved solids such as chloride, nitrate, sulfate, phosphate, sodium, magnesium, calcium, iron and aluminum. The presence of these substances increases the conductivity of a body of water. According to WHO standards, the permissible value for conductivity is $600 \mu \mathrm{S} / \mathrm{cm}$.
TDS is the amount of total dissolved solid in the water per liter, and the WHO and Iraqi standard value for TDS, is 500 ppm.

Results show that value of conductivity and concentration of total dissolved solids changes along the reservoir.

The concentration of TDS in Darbandikhan Reservoir ranged from $324 \mathrm{ppm}$ to $842 \mathrm{ppm}$, and the average for the entire lake was $754 \mathrm{ppm}$. The minimum value for TDS from sample 1 Qashli was at a safe limit, and the maximum value was from sample 4 Tolabi A, which is above the safe limit. Overall we can say TDS concentration in Darbandikhan Reservoir exceeds of the range that is allowed by WHO and Iraqi standards.

Conductivity like TDS is changing in the Lake from 461 $\mu \mathrm{S} / \mathrm{cm}$ to $1196 \mu \mathrm{S} / \mathrm{cm}$, and the average conductivity is 1057 $\mu \mathrm{S} / \mathrm{cm}$ for the lake. The minimum and maximum value are in sample 1 Qashli and sample 4 Tolabi A like TDS. If the results are compared to the acceptable values for conductivity, it showed that except sample 1 Qashli all other samples exceed the safe limit.

\subsubsection{Turbidity and Nitrates}

Turbidity and Nitrate in Darbandikhan reservoir changed from one place to another place, and the results of these two parameters are shown in the Table 6 and 7 .

Turbidity is the amount of total suspended particulates and the measure of degree to water loss transparency. The permissible value for turbidity is 5 NTU according to WHO standards.

Table 7: Results of turbidity in Darbandikhan Reservoir

\begin{tabular}{|c|c|c|}
\hline Sample No. & Sampling Location & Turbidity (NTU) \\
\hline 1 & Qashli & 6.60 \\
\hline 2 & Berke & 2.78 \\
\hline 3 & Chamarash & 2.67 \\
\hline 4 & Tolabi A & 4.94 \\
\hline 5 & Bashi Pirak & 13.6 \\
\hline 6 & mixed point & 2.75 \\
\hline 7 & Nergzajar A & 2.64 \\
\hline 8 & Nergzajar B & 2.53 \\
\hline 9 & Tolabi B & 2.22 \\
\hline 10 & Kani Kawa & 2.57 \\
\hline 11 & D/S & 2.75 \\
\hline
\end{tabular}

The maximum value for turbidity was observed as 13.6 NTU from sample 5 Bashi Pirak, and the high value of turbidity might be due to the shallow depth of the reservoir at this location, which was 7 meters. The rest of the values of turbidity were close to each other, sample 1 and sample 5, not in the safe limit and out of the limit i.e. 5 NTU. The ranges of turbidity in the reservoir were from 2.22 to 13.6 NTU, and the average turbidity value was 4.19 NTU which can be said a safe limit. Nitrate is the concentration of one nitrogen and three atoms of oxygen, produced from sewage and non-point source pollutions, and the permissible value for nitrate is $50 \mathrm{mg} / \mathrm{l}$ as given by the WHO standards. 


\section{International Journal of Science and Research (IJSR) \\ ISSN (Online): 2319-7064 \\ Index Copernicus Value (2013): 6.14 | Impact Factor (2014): 5.611}

Table 8: Results of nitrate concentration in the lake

\begin{tabular}{|c|c|c|}
\hline Sample No. & Sampling Location & Total Hardness $\mathrm{mg} / \mathrm{l}$ \\
\hline 1 & Qashli & 80 \\
\hline 2 & Berke & 90 \\
\hline 3 & Chamarash & 80 \\
\hline 4 & Tolabi A & 160 \\
\hline 5 & Bashi Pirak & 64 \\
\hline 6 & mixed point & 100 \\
\hline 7 & Nergzajar A & 76 \\
\hline 8 & Nergzajar B & 80 \\
\hline 9 & Tolabi B & 72 \\
\hline 10 & Kani Kawa & 100 \\
\hline 11 & D/S & 69.8 \\
\hline
\end{tabular}

Nitrates in the water samples ranged from 2.7 to $6.6 \mathrm{ppm}$, and the average for the nitrate result was $4.75 \mathrm{ppm}$, which was safe limit. Variations in nitrate concentration at different locations in the reservoir was mainly due to nutrients from the catchment and sewage inflows from the nearby town or by seepages of waste water from the subsurface, as some houses were close to the lake. The minimum observed concentration was in sample 4 Tolabi A, which depicts less nutrient and sewage inflow at this location. The maximum nitrates concentration was found in sample 7 Nergzajar A which is the main source of the lake, and it was $6.6 \mathrm{ppm}$. Having a higher concentration of nitrate at that source may have influenced by the sewage from Sulaymaniah City, because sewage of that city enters Tanjero River and this river is the main water source of the lake.

\subsubsection{Total Hardness and Chloride}

The total hardness and chlorides are tested to determine water quality, and according to the $\mathrm{WHO}$, the permissible value for total hardness are shown $100 \mathrm{mg} / \mathrm{l}$ and for chloride is $250 \mathrm{mg} / \mathrm{l}$. the results of total hardness shown in table 8 and chlorides shown in the Table 9.

Table 9: Concentration of total hardness.

\begin{tabular}{|c|c|c|}
\hline Sample No. & Sampling Location & Total Hardness $\mathrm{mg} / \mathrm{l}$ \\
\hline 1 & Qashli & 80 \\
\hline 2 & Berke & 90 \\
\hline 3 & Chamarash & 80 \\
\hline 4 & Tolabi A & 160 \\
\hline 5 & Bashi Pirak & 64 \\
\hline 6 & mixed point & 100 \\
\hline 7 & Nergzajar A & 76 \\
\hline 8 & Nergzajar B & 80 \\
\hline 9 & Tolabi B & 72 \\
\hline 10 & Kani Kawa & 100 \\
\hline 11 & D/S & 69.8 \\
\hline
\end{tabular}

It was found from the results that the total hardness ranged from 64 to $160 \mathrm{mg} / \mathrm{l}$, and the average total hardness for the 11 samples is $83.35 \mathrm{mg} / \mathrm{l}$ which means the water is in a safe condition. The minimum value is determined in the sample 5 Bashi Pirak which is within range, and the maximum value of total hardness is found in sample 4 Tolabi A which is out of the safe limit.
Table 10: Results of chlorides concentration in Darbandikhan Reservoir

\begin{tabular}{|c|c|c|}
\hline Sample No. & Sampling Location & Chloride $\mathrm{mg} / \mathrm{l}$ \\
\hline 1 & Qashli & 81.7 \\
\hline 2 & Berke & 77.4 \\
\hline 3 & Chamarash & 73.1 \\
\hline 4 & Tolabi A & 60.4 \\
\hline 5 & Bashi Pirak & 73.8 \\
\hline 6 & mixed point & 85.9 \\
\hline 7 & Nergzajar A & 73.1 \\
\hline 8 & Nergzajar B & 71.0 \\
\hline 9 & Tolabi B & 98.0 \\
\hline 10 & Kani Kawa & 57.5 \\
\hline 11 & D/S & 100.1 \\
\hline
\end{tabular}

Chloride range for the samples in the lake starts from 57.7 $\mathrm{mg} / \mathrm{l}$ and ends at $100.1 \mathrm{mg} / \mathrm{l}$, and the average value of chloride concentration is 77.45 . These results for chloride within are in the safe limit, because they are less than 250 $\mathrm{mg} / \mathrm{l}$.

\subsubsection{Calcium and Iron}

Calcium and Iron are two other parameters tested for our samples, and the results are shown in table 10.

Table 11: Results of calcium and iron in Darbandikhan Reservoir

\begin{tabular}{|c|c|c|c|}
\hline $\begin{array}{c}\text { Sample } \\
\text { No. }\end{array}$ & $\begin{array}{c}\text { Sampling } \\
\text { Location }\end{array}$ & $\begin{array}{c}\text { Calcium } \\
(\text { ppm })\end{array}$ & $\begin{array}{c}\text { Iron } \\
(\text { ppm })\end{array}$ \\
\hline 1 & Qashli & 29.8 & $\mathrm{Fe}<1$ \\
\hline 2 & Berke & 28.5 & $\mathrm{Fe}<1$ \\
\hline 3 & Chamarash & 29.6 & $\mathrm{Fe}<1$ \\
\hline 4 & Tolabi A & 32.0 & $\mathrm{Fe}<1$ \\
\hline 5 & Bashi Pirak & 35.0 & $\mathrm{Fe}<1$ \\
\hline 6 & mixed point & 30.0 & $\mathrm{Fe}<1$ \\
\hline 7 & Nergzajar A & 33.3 & $\mathrm{Fe}<1$ \\
\hline 8 & Nergzajar B & 30.5 & $\mathrm{Fe}<1$ \\
\hline 9 & Tolabi B & 31.3 & $\mathrm{Fe}<1$ \\
\hline 10 & Kani Kawa & 29.7 & $\mathrm{Fe}<1$ \\
\hline 11 & D/S & 32.2 & $\mathrm{Fe}<1$ \\
\hline
\end{tabular}

The exact amount of Iron concentration could not be determined, because the instrument's minimum analyzing capacity was about $1 \mathrm{ppm}$. However, in all samples the concentration of iron was detected below $1 \mathrm{ppm}$, which is with a safe limit. Calcium concentration varies from 28.5 to $35 \mathrm{ppm}$, which means the minimum is $28.5 \mathrm{ppm}$ which is in sample 2 Berke and the maximum is $35 \mathrm{ppm}$ which is determined in sample 5 Bashi Pirak. The average result for calcium concentration was $31.08 \mathrm{ppm}$ in the whole lake, and this is in the range which means it is within the safe limit.

\subsubsection{Water Quality Index}

Water Quality Index shows the average result of all parameters, but with small changes according to the weights assigned to various parameters. [8], [9] and [10] indicated the status of the water quality index and ranges given to the values of WQI like showed in table 11. Also, values of each step for calculating WQI for sample 1 is shown in annex 5, and the results of water quality index for all samples is shown in table 12 . 


\section{International Journal of Science and Research (IJSR) \\ ISSN (Online): 2319-7064 \\ Index Copernicus Value (2013): 6.14 | Impact Factor (2014): 5.611}

Table 11: Water Quality Index values with their status

\begin{tabular}{|c|c|}
\hline WQI Values & Status \\
\hline More than 100 & Unsuitable for drinking \\
\hline 75 to 100 & Very poor water quality \\
\hline 50 to 75 & Poor water quality \\
\hline 25 to 50 & Good water quality \\
\hline 0 to 25 & Excellent water quality \\
\hline
\end{tabular}

Table 12: Spatial variation in WQI of Darbandikhan

\begin{tabular}{|c|c|c|}
\hline \multicolumn{3}{|c}{ Reservoir } \\
\hline Sample No. & Sampling Location & WQI \\
\hline 1 & Qashli & 50.5 \\
\hline 2 & Berke & 66.4 \\
\hline 3 & Chamarash & 64.5 \\
\hline 4 & Tolabi A & 78.6 \\
\hline 5 & Bashi Pirak & 86.7 \\
\hline 6 & mixed point & 66.1 \\
\hline 7 & Nergzajar A & 67.1 \\
\hline 8 & Nergzajar B & 64.8 \\
\hline 9 & Tolabi B & 65.1 \\
\hline 10 & Kani Kawa & 65.4 \\
\hline 11 & D/S & 66.0 \\
\hline
\end{tabular}

According to the results of WQI for different sites of the reservoir which are calculated from the water quality parameters, the average quality of water in different locations of the reservoir is presented. Average WQI value of those 11 samples was 67.3 which manifests poor water quality according to table 4.9, and t for our samples showed a range between 50.5 and 86.7. The minimum value which is showing that water quality is better was found in sample 1 Qashli, and the highest value of WQI which is showing the worst water quality in the lake was determined in sample 5 Bashi Pirak.

In general, the quality of water is poor, but sample 5 Bashi Pirak and sample 4 Tolabi A have very poor water quality. Sample 5 is taken where the depth of water 7 meters, and the sample 4 was taken where a village was very close to the reservoir which might be the big reason behind the big difference to other samples in the lake.

\subsubsection{Effect of Climate on Water Quality}

In order to see the effect of climate variability on water quality of the reservoir, the correlation between major climate parameters (rainfall and temperature) is found. Correlations ranges from -1 to +1 . If it is close to +1 it means by the of rainfall or water temperature, the concentration of that different parameter will also increase. On the other hand, if it is close to -1 it means by the decrease of rainfall or water temperature the concentration of different parameter will decrease. If it is close to zero it means there is no correlation between rainfall or water temperature and the water quality parameters. Based on these correlations, the regression analysis was also performed and the regression equations were found in order to predict the water quality based on climate data. The correlations are found by using secondary data which was collected from the Directorate of Darbandikhan Dam, which they collect monthly through upstream and downstream of the dam. The secondary data of water temperature and rainfall are shown in table 13 and 14.

Table13: Secondary data of water temperature is shown

\begin{tabular}{|c|c|c|c|c|c|c|c|c|c|c|c|c|}
\hline $\begin{array}{c}\text { periods/ } \\
\text { parameters }\end{array}$ & Turbidity & $\mathrm{PH}$ & Conductivity & T.D.S & $\mathrm{Fe}$ & Calcium & Magnesium & Sulphates & $\begin{array}{l}\text { Total } \\
\text { Hardness }\end{array}$ & $\begin{array}{l}\text { Total } \\
\text { Alkalinity }\end{array}$ & Nitrite & $\begin{array}{l}\text { Water } \\
\text { temprature }\end{array}$ \\
\hline $26-12-12$ & 12.5 & 8.01 & 503 & 256 & 0.15 & 42 & 80 & 56 & 217 & 145 & 0.013 & 12.5 \\
\hline $26-01-13$ & 5.62 & 7.95 & 582 & 289 & 0.35 & 45 & 85 & 58 & 170 & 145 & 0.03 & 18 \\
\hline $26-02-13$ & 4.41 & 8.34 & 537 & 270 & 0.1 & 57 & 100 & 55 & 165 & 150 & 0.095 & 14.8 \\
\hline $25-03-13$ & 1.54 & 8.4 & 576 & 286 & 0.15 & 53 & 100 & 60 & 185 & 150 & 0.049 & 15 \\
\hline 24-04-13 & 3.7 & 8.5 & 493 & 247 & 0.2 & 40 & 100 & 50 & 150 & 110 & 0.072 & 20.4 \\
\hline $27-05-13$ & 2.7 & 8.4 & 465 & 232 & 0.15 & 35 & 90 & 45 & 175 & 95 & 0.036 & 19.5 \\
\hline $27-06-13$ & 3.27 & 8.74 & 364 & 182 & 1 & 21 & 100 & 46 & 140 & 55 & 0.026 & 26.2 \\
\hline $21-07-13$ & 2.66 & 8.9 & 382 & 191 & 0.35 & 30 & 80 & 51 & 135 & 60 & 0.03 & 24 \\
\hline $26-01-14$ & 3.18 & 9.98 & 603 & 300 & 0.15 & 58 & 100 & 59 & 175 & 120 & 0.01 & 13.1 \\
\hline $26-02-14$ & 7.21 & 8.3 & 606 & 306 & 0.15 & 52 & 60 & 54 & 170 & 155 & 0.046 & 16.5 \\
\hline $26-03-14$ & 4.5 & 8.39 & 586 & 294 & 0.15 & 51 & 70 & 5.3 & 165 & 130 & 0.079 & 15.6 \\
\hline $28-04-14$ & 3.9 & 8.28 & 523 & 264 & 0.15 & 60 & 100 & 81 & 175 & 170 & 0.109 & 20 \\
\hline $26-05-14$ & 5.41 & 8.45 & 449 & 273 & 0.15 & 29 & 70 & 17 & 160 & 100 & 0.079 & 23 \\
\hline $29-06-14$ & 2.48 & 8.53 & 387 & 194 & 0.15 & 17 & 75 & 53 & 120 & 50 & 0.095 & 26 \\
\hline $24-07-14$ & 3.28 & 8.41 & 447 & 221 & 0.15 & 23 & 70 & 54 & 145 & 90 & 0.046 & 27.5 \\
\hline $25-08-14$ & 3.13 & 8.15 & 438 & 213 & 0.15 & 24 & 100 & 57 & 175 & 105 & 0.049 & 23 \\
\hline $21-09-14$ & 3.41 & 8.2 & 500 & 255 & & 43 & 100 & 56 & 180 & 90 & 0.068 & 23 \\
\hline $21-10-14$ & 2.58 & 7.95 & 563 & 279 & & 44 & 80 & 63 & 190 & 110 & 0.032 & 18 \\
\hline $21-11-14$ & 5.3 & 7.9 & 602 & 303 & & & 100 & 59 & 185 & 155 & 0.158 & 16 \\
\hline correlations & -0.444 & 0.011 & -0.825 & -0.788 & 0.399 & -0.824 & -0.129 & -0.072 & -0.729 & -0.780 & 0.030 & \\
\hline
\end{tabular}




\section{International Journal of Science and Research (IJSR) ISSN (Online): 2319-7064}

Index Copernicus Value (2013): 6.14 | Impact Factor (2014): 5.611

Table14: Rainfall data is shown.

\begin{tabular}{|c|c|c|c|c|c|c|c|c|c|c|c|c|}
\hline $\begin{array}{c}\text { periods/ } \\
\text { parameters }\end{array}$ & Turbidity & $\mathrm{PH}$ & $\begin{array}{l}\text { Conducti } \\
\text { vity }\end{array}$ & T.D.S & $\mathrm{Fe}$ & Calcium & Magnesium & Sulphates & $\begin{array}{l}\text { Total } \\
\text { Hardness }\end{array}$ & $\begin{array}{l}\text { Total } \\
\text { Alkalinity }\end{array}$ & Nitrite & $\begin{array}{l}\text { total } \\
\text { Rainfall in } \\
\text { that month }\end{array}$ \\
\hline $26-12-12$ & 12.5 & 8.01 & 503 & 256 & 0.15 & 42 & 80 & 56 & 217 & 145 & 0.013 & 78.3 \\
\hline 26-01-13 & 5.62 & 7.95 & 582 & 289 & 0.35 & 45 & 85 & 58 & 170 & 145 & 0.03 & 159.6 \\
\hline $26-02-13$ & 4.41 & 8.34 & 537 & 270 & 0.1 & 57 & 100 & 55 & 165 & 150 & 0.095 & 92.0 \\
\hline 25-03-13 & 1.54 & 8.4 & 576 & 286 & 0.15 & 53 & 100 & 60 & 185 & 150 & 0.049 & 14.0 \\
\hline 24-04-13 & 3.7 & 8.5 & 493 & 247 & 0.2 & 40 & 100 & 50 & 150 & 110 & 0.072 & 12.0 \\
\hline $27-05-13$ & 2.7 & 8.4 & 465 & 232 & 0.15 & 35 & 90 & 45 & 175 & 95 & 0.036 & 106.8 \\
\hline 27-06-13 & 3.27 & 8.74 & 364 & 182 & 1 & 21 & 100 & 46 & 140 & 55 & 0.026 & 0.0 \\
\hline 21-07-13 & 2.66 & 8.9 & 382 & 191 & 0.35 & 30 & 80 & 51 & 135 & 60 & 0.03 & 0.0 \\
\hline 26-01-14 & 3.18 & 9.98 & 603 & 300 & 0.15 & 58 & 100 & 59 & 175 & 120 & 0.01 & 80.0 \\
\hline $26-02-14$ & 7.21 & 8.3 & 606 & 306 & 0.15 & 52 & 60 & 54 & 170 & 155 & 0.046 & 3.6 \\
\hline $26-03-14$ & 4.5 & 8.39 & 586 & 294 & 0.15 & 51 & 70 & 5.3 & 165 & 130 & 0.079 & 124.0 \\
\hline $28-04-14$ & 3.9 & 8.28 & 523 & 264 & 0.15 & 60 & 100 & 81 & 175 & 170 & 0.109 & 7.6 \\
\hline $26-05-14$ & 5.41 & 8.45 & 449 & 273 & 0.15 & 29 & 70 & 17 & 160 & 100 & 0.079 & 8.8 \\
\hline 29-06-14 & 2.48 & 8.53 & 387 & 194 & 0.15 & 17 & 75 & 53 & 120 & 50 & 0.095 & 0.2 \\
\hline 24-07-14 & 3.28 & 8.41 & 447 & 221 & 0.15 & 23 & 70 & 54 & 145 & 90 & 0.046 & 0.0 \\
\hline $25-08-14$ & 3.13 & 8.15 & 438 & 213 & 0.15 & 24 & 100 & 57 & 175 & 105 & 0.049 & 0.0 \\
\hline 21-09-14 & 3.41 & 8.2 & 500 & 255 & & 43 & 100 & 56 & 180 & 90 & 0.068 & 0.0 \\
\hline $21-10-14$ & 2.58 & 7.95 & 563 & 279 & & 44 & 80 & 63 & 190 & 110 & 0.032 & 47.4 \\
\hline 21-11-14 & 5.3 & 7.9 & 602 & 303 & & & 100 & 59 & 185 & 155 & 0.158 & 145.8 \\
\hline correlations & 0.290 & -0.183 & 0.574 & 0.531 & -0.145 & 0.421 & 0.073 & -0.152 & 0.403 & 0.464 & 0.128 & \\
\hline
\end{tabular}

\subsubsection{Effect of rainfall on water quality parameters}

Rainfall and water quality Data at the reservoir from December of 2012 to December of 2014 were used in order to find the correlations. The results of the analysis are given in the Table 15.

Table 15: Result of correlation between rain fall and WQ parameters.

\begin{tabular}{|c|c|}
\hline Parameters & Correlations \\
\hline Turbidity & 0.290 \\
\hline PH & -0.183 \\
\hline Conductivity & 0.574 \\
\hline T.D.S & 0.531 \\
\hline Fe & -0.145 \\
\hline Calcium & 0.421 \\
\hline Magnesium & 0.073 \\
\hline Sulfates & -0.152 \\
\hline Total Hardness & 0.403 \\
\hline Total Alkalinity & 0.464 \\
\hline Nitrite & 0.128 \\
\hline
\end{tabular}

\section{correlations}

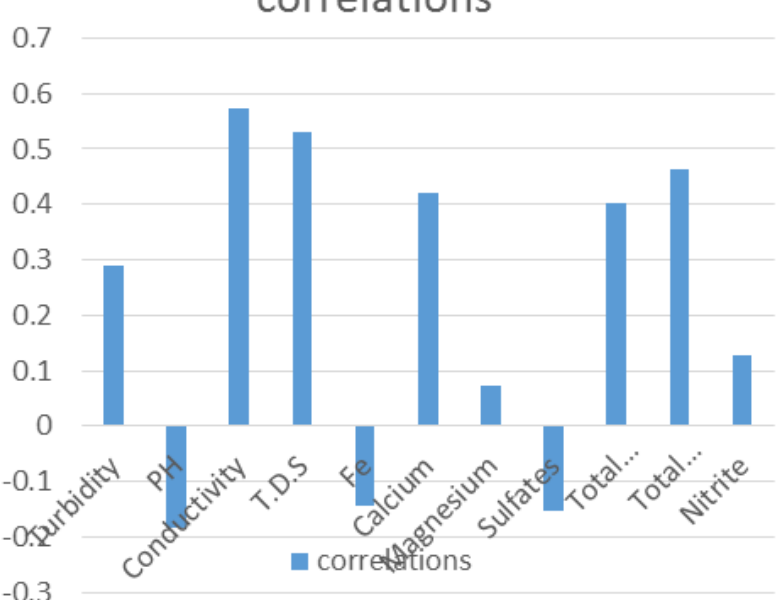

Figure 4: Correlation between rainfall and water quality parameters
According to the results, no significant correlations were found between rainfall and water quality parameters except TDS and conductivity which have positive correlations, and they are +0.531 and +0.537 . These two correlations show that by increasing rainfall, the concentration of these two parameters will increase. However, the $\mathrm{pH}, \mathrm{Fe}$ and sulphates have negative correlation, whereas other parameters like turbidity, calcium, total hardness and alkalinity have positive correlations in the range of 0.30 to 0.45 . Also, the correlation between rainfall and magnesium was 0.073 and close to zero, and this means that the correlation between them was very less compared to the other parameters.

\subsubsection{Effect of water temperature on water quality parameters}

Also, correlations found between water temperature and water quality parameters in order to know how temperature affects the quality of water, and the results are shown in the Table 14.

Table 16: Correlations between water temperature and WQ parameters

\begin{tabular}{|c|c|}
\hline Parameters & Correlations \\
\hline Turbidity & -0.444 \\
\hline PH & 0.011 \\
\hline Conductivity & -0.825 \\
\hline T.D.S & -0.788 \\
\hline Fe & 0.399 \\
\hline Calcium & -0.824 \\
\hline Magnesium & -0.129 \\
\hline Sulphates & -0.072 \\
\hline Total Hardness & -0.729 \\
\hline Total Alkalinity & -0.780 \\
\hline Nitrite & 0.030 \\
\hline
\end{tabular}

Volume 4 Issue 12, December 2015 


\section{International Journal of Science and Research (IJSR) \\ ISSN (Online): 2319-7064}

Index Copernicus Value (2013): 6.14 | Impact Factor (2014): 5.611

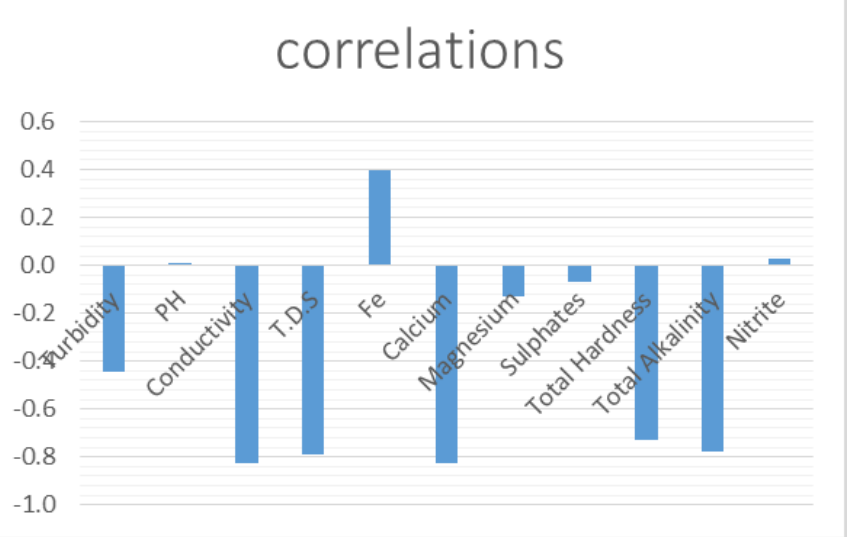

Figure 5: Correlations between water temperature and water quality parameters.

According to the previous data which were collected from the Darbandikhan Dam Directorate, correlations were found between water temperature and water quality parameters. The results of correlation between which has the negative correlation and close to -1 was calcium and conductivity which are -0.824 and -0.825 . These results mean that by increasing the temperature of water, the concentration of these two parameters decreased. Also, the correlation between water temperature and $\mathrm{pH}$ was +0.011 , and it is close to zero which means there was no correlation between them.

\section{Conclusion}

For analyzing and determining water quality in Darbandikhan Reservoir physical and chemical properties of the water were chosen. Then, the requirements of this research included like collecting data from the two previous years from directorate of the dam and taking eleven samples from different sites of the reservoir. Then statistical analyses and calculations were done to decide on the quality of the water in the reservoir. The following conclusion were made:

1. Based on WQI which is used for deciding on water quality in the lake, Darbanddikhan Reservoir has poor water quality and in some parts has very poor quality. The quality of water in Darbandikhan Reservoir is not suitable for drinking directly (without treatment), but it can be used for other purposes.

2. It has been found that some parameters of water quality are affected by climate variations like rainfall and water temperature. There is correlation between some of them either directly proportional such as TDS and conductivity with rainfall or inversely proportional such TDS and conductivity with water temperature, but some of the parameters were not affected by the climate like magnesium is not affected by rainfall and nitrite is not affected by water temperature.

3. Regression equations between water quality parameters showed that if there is a good relationship between water quality parameters, then measurement of a parameter can be used for predicting another parameter, for example TDS and conductivity.

\section{Recommendations}

The following recommendations are suggested based on the requirements and results of this study:

1. Monitor the entire reservoir monthly and seasonally, including samples in the upstream and downstream of the dam in order to know which site of the reservoir has better water quality.

2. Increase the number of water quality parameters for the tests which are going to be done, because it gives more accurate results of the water quality.

3. Working on the geometry and the formation of the reservoir. For example, the type and formation of the soils and rocks in the reservoir and around it, because it may impact on the quality of water. So, knowing all the impacts on the water quality can give a suitable solution for those circumstances.

4. Try to avoid mixing sewage from the villages near the lake with the water of the reservoir, and also try to minimize the effects of sewages from Sulaymaniah City on the Tanjero River which is one of the main resources of the lake.

\section{Acknowledgement}

Analyzing water quality in Darbandikhan Reservoir study and report were the outcome of a cooperative effort between staff at the University of Kurdistan-Hewler who helped and supported achieve these results me to reach this level of capability.

\section{References}

[1] Venkatesharaju, K., Ravikumar, P., Somashekar, R.K., Prakash. K.L., " Physico-chemical and Bacteriological Investigation on the river Cauvery of Kollegal Stretch in Karnataka," Journal of science Engineering and technology, 6 (1), pp 50-59 (2010).

[2] Tchobanoglous, G. and E.D Schroeder, Water Quality, Addison Wesley Publishing Company Inc., Reading, Massachusetts (1987).

[3] Evans,"Important Bird Areas of the Middle East", (Birdlife Conservation Series, No. 2). Cambridge, UK, Bird Life International (1994).

[4] Jamal, Z., Mustafa, O., Al-Obaidi, G. \& Al-Saffar, M. Key Biodiversity Survey of Kurdistan, Sulaymaniah, Northern Iraq. Ministry of Environment, Publication No. NI-0310-02 (March, 2010).

[5] Hemn, Geologist in Directorate of Dabandikhan Dam Report (2015).

[6] Goran, Lab Report in Directorate of Darbandikhan $\operatorname{Dam}(2015)$

[7] Poonam, Rajesh Kumar and Ashok Yadav, "Ground Water Quality in Mohendergarh Town," Haryana (India), International Journal of pharmaceutical and chemical sciences ISSN: 2277-5000.

[8] Carmen Jacoban, Matei Macoveanu, "A Comparison of Argentometric Titration and Spectrophotometric Determination of Chloride Concentration in Precipitation Samples," 10(2), pp 2/05-2109 (2005). 
[9] Badiadka Narayana and Kenchaiah Sunil," A Spectrophotometric Method for the Determination of Nitrite and Nitrate", Eurasian J. Anal. Chem. 4(2), pp204-214, (2009).

[10]P. A. Siskos, E. P. Diamandis and E. Gillieron," Potentiometric Titration of Sulphate, Sulphite and dithionate mixtures with use of a lead ion-selective electrode", Tlanta, 30 (12), pp. 98\&982, (1983).

[11] G.Dickson,"An exact definition of total alkalinity and procedure for estimation of alkalinity and total inorganic carbon from titration data," Oceanographic research papers, 28 (6), pp 609-623, (June 1981).

[12] Elarina N. Dkhar, Paul S. Dkhar and Jasha Momo H. Anal," Trace Elements Analysis in Drinking Water of Meghalaya by Using Graphite Furnace-Atomic Absorption Spectroscopy and in Relation to Environmental and Health Issues," Hindawi Publishing Corporation Journal of Chemistry, Article ID 975810, 8 pages,(2014).

[13] Stasys Tautkus, Laurastepnoneniene and Rolandas Kazlauukas," Determination of iron in natural and mineral waters by flame atomic absorption spectrometry," J.Serb.Chem.Soc, 69(5), pp.393-402, (2004).

[14] Sherry L.Wirth, Sherry L.Wirth, Sherry L.Wirth,"Drinking water bacteria", University of Nebraska-Lincoln extension, institute of Agricultur and Natural Resources, (2014).

[15] Pathak, H. \& Limaye, S.N, "Pollumeter a Water Quality Index Model for the Assessment of Water Quality, India,“ Referred academic journal, Echo Services International, (January 2011).

[16] WHO drinking water guidelines, ISBN 978924154815 1, (2011).

[17] Iraqi specification No. 1974/417 for chemical and bacteriological.

[18] Chauhan, N., J, TH," A study of Water Quality Index (WQI) of Heranj Lake, Dist. Kheda-Gujarat" Asian J. Exp. Biol. Sci,3(3),ISSN 0975-5845, pp.582-588 ((2012).

[19] Bharamal. D. L, KorgaonkarD.S," Determination of water quality index of Palnekond reservoir, ". International journal of current microbiological and applied sciences, Volume 3 ,ISSN: 2319-7706, pp. 819830, (2014).

[20] Gorde, S.P., Jadhav, M.V, Assessment of water quality parameters: a review. Int. Journal of Engineering Research and Applications, 3 (6), (ISSN 2248-9622), pp. 2029-2035, (Nov-Dec 2013).

\section{Author Profile}

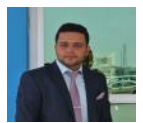

Ahmad Majid Abdulhamid recently graduated as an engineer from University of Kurdistan Howler. His major was water resources engineering and his graduation project was supervised by Dr. Saima Jadoon and Dr. Sarfraz Munir. 